\title{
STONE DUST AGGLOMERATION FOR UTILIZING AS BUILDING MATERIAL
}

\author{
Gabriel Borowski ${ }^{1}$, Tomasz Świderski ${ }^{2}$, Małgorzata Ozga' \\ 1 Lublin University of Technology, Faculty of Environmental Engineering, Nadbystrzycka 40b St., 20-618 Lublin, \\ Poland, e-mail: g.borowski@pollub.pl \\ 2 Polskie Górnictwo Skalne Sp. z o.o. (Polish Rock Mining Company), Chałubińskiego 42 St., 25-619 Kielce, \\ Poland
}

Received: 2017.08.28

Accepted: 2017.11.02

Published: 2017.12.05

\begin{abstract}
In the paper we discuss the possibility of using stone dust for utilizing as building material. The tested material was amphibolite, found in the Sudeten Mountains and the Tatra Mountains in Poland. The chemical composition of dust was determined by means of spectrometry methods. Moreover, the basic physical properties of the material were designated. Stone dust was mixed with starch or cement binder. The binder addition was from $5 \%$ to $20 \%$ by weight. The water content was adjusted to about $25 \%$ humidity. The mixture was then compressed in a hydraulic press at $50 \mathrm{MPa}$. The results of the mechanical toughness of agglomerates were shown. On the basis of the results, acceptable toughness of agglomerates was found, with the addition of cement in mass share $20 \%$ and seasoning for 48 hours. However, starch was not suitable as a binder for agglomeration of amphibolite.
\end{abstract}

Keywords: agglomeration, stone dust, amphibolite, utilization

\section{INTRODUCTION}

Broken aggregates of stone are basic raw materials used mainly in construction, almost from the beginning of civilization. Obtaining specific fractions of aggregates, thanks to the use of specialized machinery and equipment and processing technology, results in significant amounts of dusts. In Poland, the production of aggregates in 2011-2014 amounted from 6.216.000 up to 10.497.000 tons per year [15].

Stone dust is produced by the process of cutting into bricks and cleaning, where it is necessary to use dust extraction systems or water flushing systems. These fractions often exhibit strong mutual attraction, hence the need for separation techniques from coarse particles [14]. Stone dust is used increasingly often to produce road pavements $[8,9]$. It is also interesting to use dust for agricultural purposes [5]. Delivery of stone dust to barren soil causes re-mineralization, as stone is the source of many elements and minerals. Another direction for the use of dust is the ceramic industry, as a component of ceramic tile clinker, and glass industry [15]. The possibility of using basalt dust in cement mortars has been demonstrated [4]. This dust, used as a substitute for sand, increases the strength of cement mortars [2]. It fills the pores in the cement matrix and seals the structure of the mortar with increasing its density. Additionally, it exhibits pozzolanic properties. The addition of basalt dust also increases frost resistance of cement mortars and concrete [3]. Stone dust (granite) was recycled by incorporating it into building materials. Bricks were made in order to study their properties. It was found that the compressive strength of bricks depended on the percentage of dust mixed with fly ash [13]. The above-mentioned discussion proves that the incorporation of stone dust as replacement can solve a part of the problem associated with waste disposal (Fig. 1). 


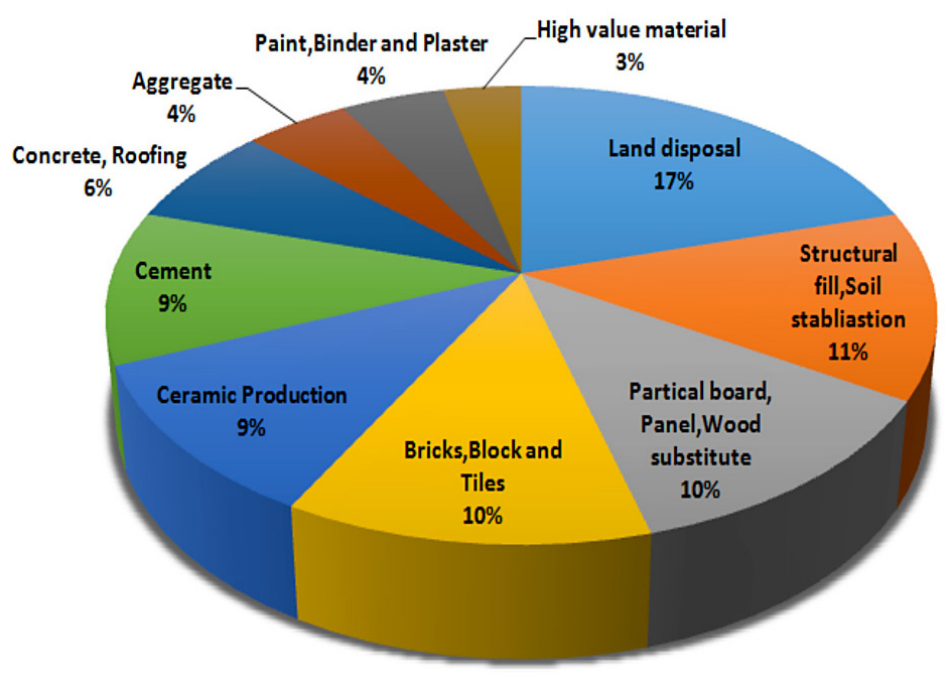

Fig. 1. Stone dust utilization [10]

Stone dust is a serious environmental problem because it is a non-biodegradable material. Stone dust dumped on land can reduce the rate of rain water percolating and deteriorate soil fertility. When dumped in rivers and streams, it contaminates the water. Stone dust can be utilized for developing low cost building materials such as block, brick, tiles etc. [10]. A building product was presented consisting mainly of limestone dust, mixed with Portland cement [6]. They showed that quarry dust-cement mixtures can be used for the production of molded masonry bricks with acceptable mechanical properties. Various methods of agglomerating fine-dust materials, including briquetting, pelletizing and granulation have been investigated [1]. Commonly, there are mineral or organic binders used for agglomeration processes. Morover, binderless briquetting was found to be successful in the case of the fine and ultra-fine coking coals [12].

The goal of this study is to investigate the possibility of utilizing the stone dust agglomerate as building material. This stone, named amphibolite, are widespread in Poland and are found in the Sudeten Mountains as well as the Tatra Mountains.

\section{MATERIAL AND METHODS}

The material we investigated was amphibolite stone dust. Amphibolite is a metamorphic rock, dark green, dark gray, black or brown in color. The main minerals are amphiboles as well as quartz, epidot, zoisite, grenadine, biotite, cordi- erite, andalusite, sillimanite, tourmaline, titanite, ilmenite and pyroxene.

The material was delivered by the Quarry "Piława Górna" located in Lower Silesia. It is one of the largest raw material fields in Poland for the production of broken aggregates of stone. Production capacity of the mine is about 7.5 million tons per year. Crushed stone is used for the construction of roads. railway lines, and as an ornamental stone to diversify the gardens, whereas stone dust is used for the production of mineral asphalt, mechanically stabilized substructures and high strength concrete.

The mineral composition was analyzed by the X-ray diffraction (XRD) method (Fig. 2). XRD test of mineral composition are aimed at determining the presence of individual elements (qualitative analysis) and the percentage content of compounds (quantitative analysis).

Percentage of chemical compounds was determined with the spectrometry method of fusion-inductively coupled plasma (FUS-ICP). The presence of the most important elements was determined using a spectrometer of total digestioninductively coupled plasma (TD-ICP) and the method of instrumental neutron activation analysis (INAA). The gradation of stone dust was specified by means of sieve analysis, according to the Polish standard PN-EN 933-1. The basic physical properties of the material were designated and shown in Table 1.

Stone dust was mixed with two types of binders: organic (starch) and mineral (cement). Mixing was carried out with an electric vertical mixer, where the binder was added. The binder 


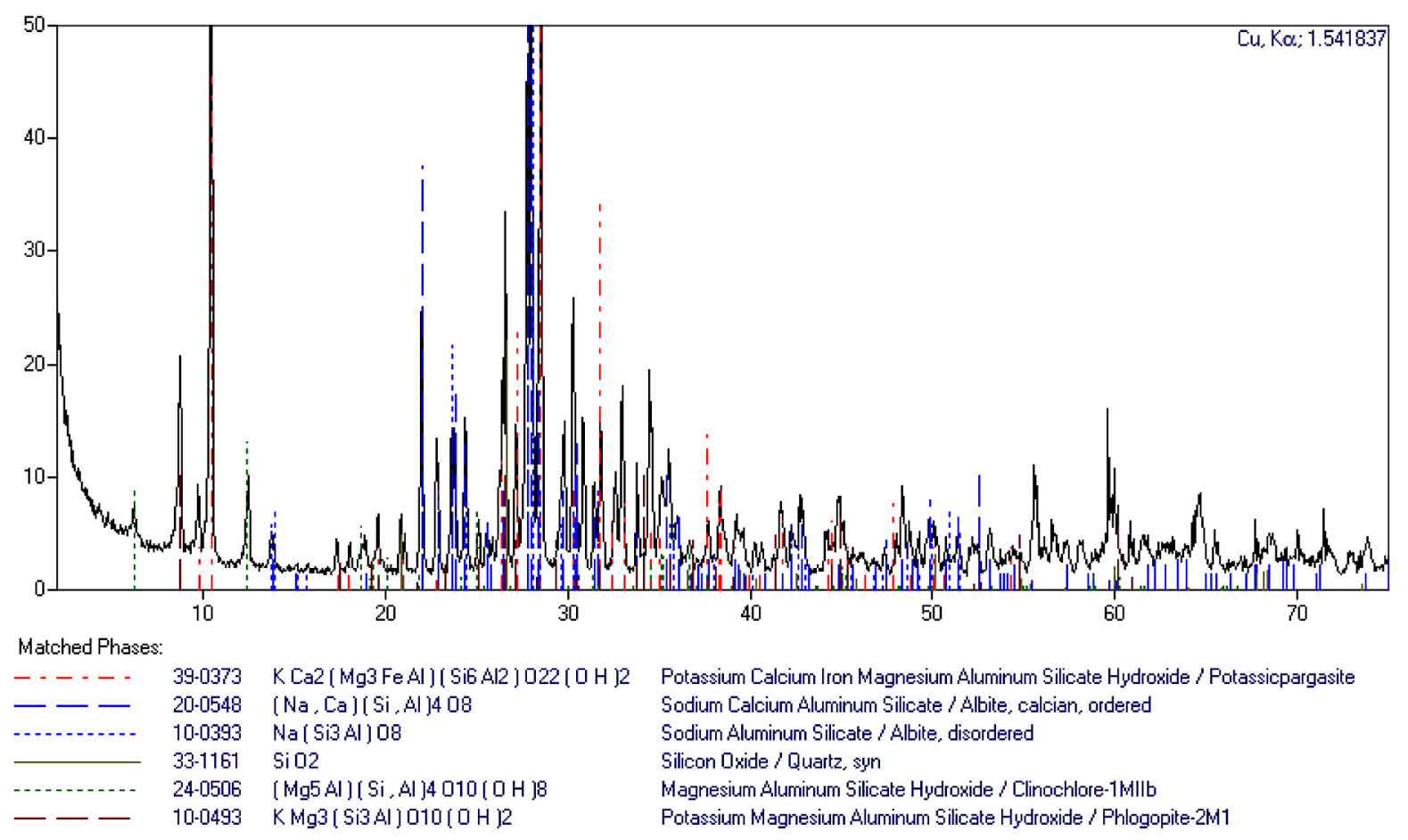

Fig. 2. Sample of XRD of amphibolite stone dust

Table 1. Physical properties of amphibolite stone dust

\begin{tabular}{|l|c|c|c|}
\hline \multicolumn{1}{|c|}{ Properties } & Standard & Unit & Result \\
\hline The content of remains & PN-EN 933-1 & $\%$ & 8.60 \\
\hline Flow indicator & PN-EN 933-6 & $\mathrm{s}$ & 42.0 \\
\hline Dust quality & PN-EN 933-9 & $\mathrm{g} / \mathrm{kg}$ & 1.00 \\
\hline Volumetric density & PN-EN 1097-6 & $\mathrm{Mg} / \mathrm{m}^{3}$ & 2.90 \\
\hline Bulk density & PN-EN 1097-3 & $\mathrm{Mg} / \mathrm{m}^{3}$ & 1.65 \\
\hline Absorptivity & PN-EN 1097-6 & $\%$ & 0.50 \\
\hline Fat pollutions & PN-EN 1744-1 & $\%$ & 0.00 \\
\hline
\end{tabular}

addition was from $5 \%$ to $20 \%$ by weight. During mixing, water content was adjusted to about $25 \%$ humidity. The mixture was then compressed in a hydraulic press at $50 \mathrm{MPa}$ (Fig. 3). The press was equipped with a molding matrix consisting of a cylindrical die and a punch (Fig. 4), allowing two samples to be made simultaneously. We obtained uniform agglomerates (briquettes) having a cylindrical shape, a diameter of $28 \mathrm{~mm}$ and a height of $14 \mathrm{~mm}$ (Fig. 5).

For further study of mechanical toughness, both new-made and seasoned samples were selected. Seasoning consisted in storing samples in a closed airy room for a few days to several weeks after they were made. The toughness of the agglomerates was determined using the gravitational drop test. Samples were dropped three times from a height of $2.0 \mathrm{~m}$ onto a metal base, and weight loss was measured after every drop. Than percentage Impact Strength Index was calculated - minimum index should be at least $90 \%$ [1].

\section{RESULTS AND DISCUSSION}

\section{Chemical composition and grain size}

Table 2 shows the percentage of chemical compounds comprised in the amphibolite stone dust. The presence of the most important elements is shown in Table 3 . The results of sieve analysis of stone dust are shown in Table 4.

On the basis of data, a high proportion of silicates in the tested material was found, ranging from $49.66 \%$ to $58.38 \%$. Alumina and iron oxides also have a significant share, with a combined 


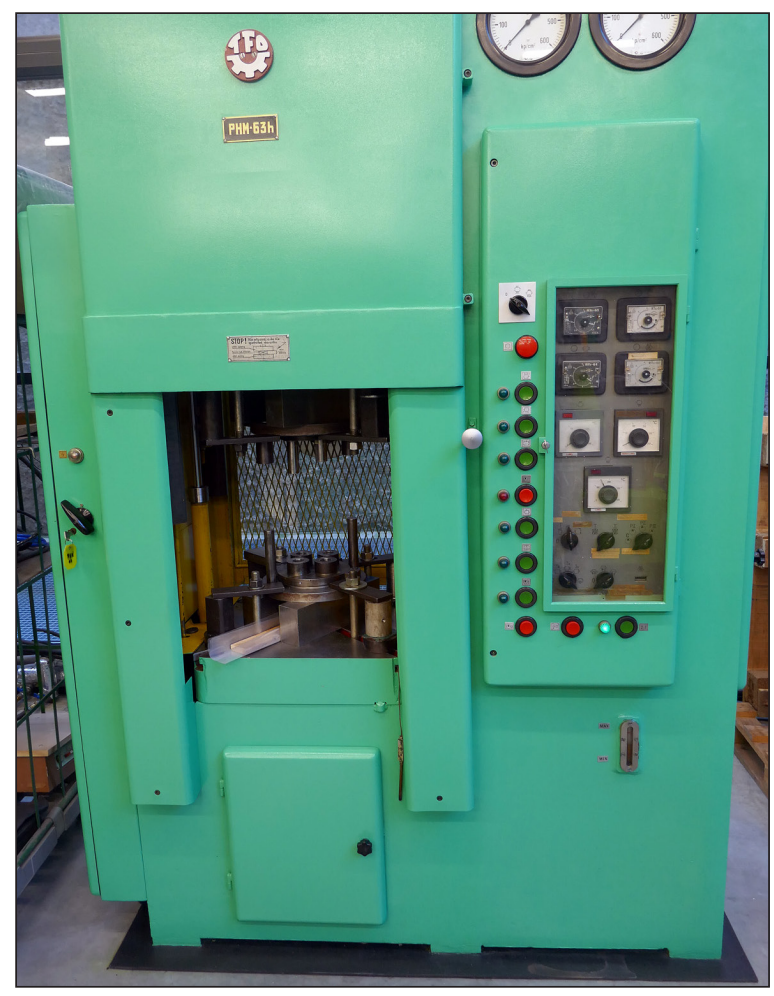

Fig. 3. Hydraulic press (Phot. G. Borowski)
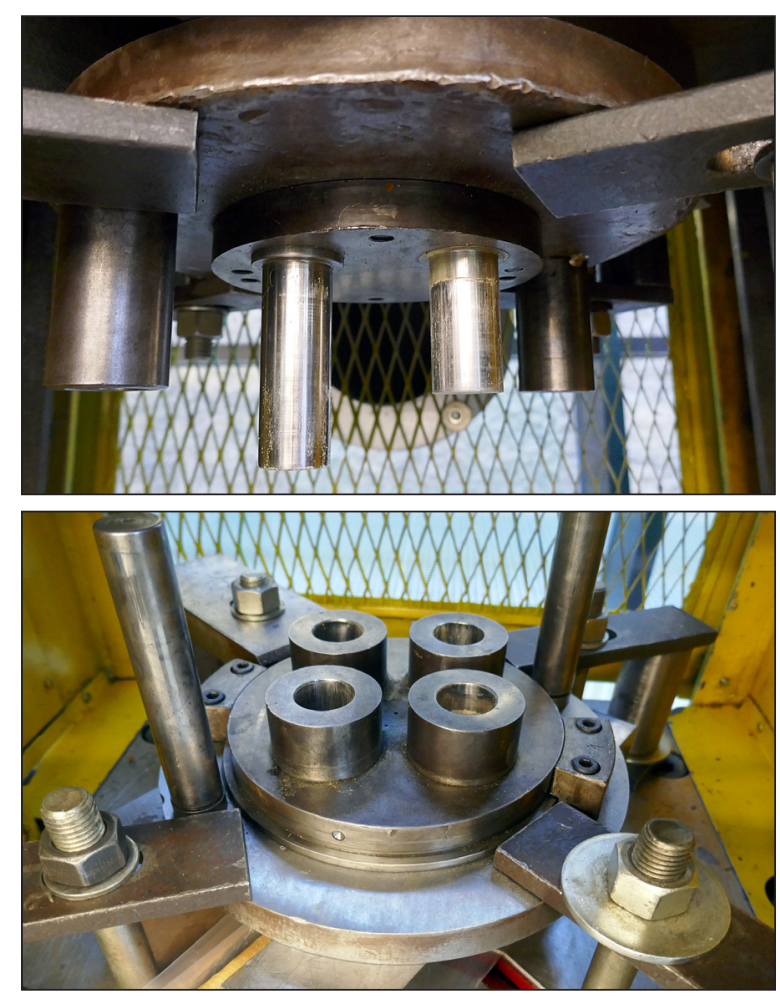

Fig. 4. Molding matrix (Phot. G. Borowski)

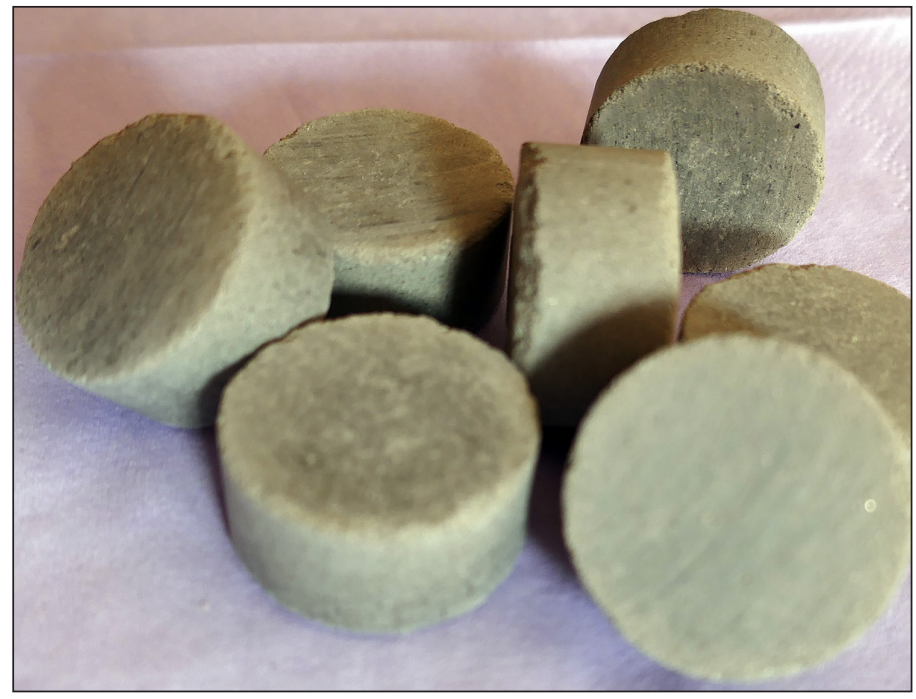

Fig. 5. Look of agglomerates (Phot. G. Borowski)

Table 2. Chemical compounds of the amphibolite stone dust

\begin{tabular}{|c|c|c|c|c|}
\hline \multirow{2}{*}{ Compound name } & \multicolumn{3}{|c|}{ Chemical compound content [\%] } \\
\cline { 2 - 5 } & Stone dust & Dust from the collector & $\begin{array}{c}\text { Dust from the dump } \\
0-2 \mathrm{~mm}\end{array}$ & $\begin{array}{c}\text { Dust from the dump } \\
0-5 \mathrm{~mm}\end{array}$ \\
\hline $\mathrm{SiO}_{2}$ & 49.66 & 57.88 & 58.38 & 56.13 \\
\hline $\mathrm{Al}_{2} \mathrm{O}_{3}$ & 15.56 & 15.22 & 15.8 & 16.04 \\
\hline $\mathrm{Fe}_{2} \mathrm{O}_{3 \text { total }}$ & 11.73 & 9.37 & 8.33 & 9.92 \\
\hline $\mathrm{CaO}$ & 9.49 & 5.34 & 3.83 & 5.19 \\
\hline $\mathrm{MgO}$ & 6.96 & 4.26 & 3.9 & 4.36 \\
\hline $\mathrm{Na}_{2} \mathrm{O}$ & 2.84 & 2.39 & 2.94 & 2.22 \\
\hline $\mathrm{TiO}_{2}$ & 1.99 & 1.06 & 1.04 & 1.19 \\
\hline $\mathrm{K}_{2} \mathrm{O}$ & 0.49 & 1.70 & 1.94 & 1.98 \\
\hline $\mathrm{P}_{2} \mathrm{O}_{5}$ & 0.23 & 0.20 & 0.15 & 0.12 \\
\hline $\mathrm{MnO}$ & 0.19 & 0.21 & 0.20 & 0.25 \\
\hline
\end{tabular}


Table 3. Content of the most important chemical elements

\begin{tabular}{|c|c|c|c|c|}
\hline \multirow{2}{*}{ Name of the element } & \multicolumn{4}{|c|}{ Content of chemical elements [ppm] } \\
\cline { 2 - 5 } & Stone dust & Dust from the collector & $\begin{array}{c}\text { Dust from the dump } \\
0-2 \mathrm{~mm}\end{array}$ & $\begin{array}{c}\text { Dust from the dump } \\
0-5 \mathrm{~mm}\end{array}$ \\
\hline $\mathrm{Ba}$ & 89 & 522 & 596 & 569 \\
\hline $\mathrm{V}$ & 302 & 238 & 193 & 250 \\
\hline $\mathrm{Sr}$ & 284 & 150 & 179 & 155 \\
\hline $\mathrm{Zr}$ & 196 & 209 & 153 & 151 \\
\hline $\mathrm{Cr}$ & 169 & 132 & 121 & 134 \\
\hline $\mathrm{Cu}$ & 152 & 86 & 58 & 134 \\
\hline $\mathrm{Zn}$ & 123 & 128 & 136 & 77 \\
\hline $\mathrm{Ni}$ & 95 & 84 & 59 & 44 \\
\hline $\mathrm{Co}$ & 49 & 38 & 28 & 34 \\
\hline $\mathrm{Sc}$ & 36 & 26 & 23 & 32 \\
\hline $\mathrm{Y}$ & 30 & 32 & 27 & 36 \\
\hline $\mathrm{Ce}$ & 24 & 47 & 52 & 22 \\
\hline $\mathrm{Nd}$ & 14 & 25 & 16 & 17 \\
\hline $\mathrm{La}$ & 12 & 27 & 29 & \\
\hline
\end{tabular}

Table 4. Results of sieve analysis of stone dust

\begin{tabular}{|c|c|c|}
\hline Sieve mesh size $[\mathrm{mm}]$ & Residual material [\%] & Screened material [\%] \\
\hline 4.0 & 0 & 100 \\
\hline 2.8 & 0 & 100 \\
\hline 2.0 & 9 & 91 \\
\hline 1.0 & 28 & 63 \\
\hline 0.5 & 19 & 43 \\
\hline 0.25 & 17 & 27 \\
\hline 0.125 & 12 & 15 \\
\hline 0.063 & 6 & 8.6 \\
\hline 0.0 & 8.6 & - \\
\hline
\end{tabular}

value of $25.48 \%$, on average. The outstanding metal oxides represent an average share of about $22.5 \%$. Among the elements, the highest content was found in the case of barium, as well as vanadium, strontium, zirconium, chromium and zinc. Other metals, including rare earth metals, are present in the amounts lower than the vanadium alone, which is regarded as an additive in the production of high quality steel.

The chemical composition of amphibolite dust is very similar to the composition of basalt dust [11]. Silicon oxide $\mathrm{SiO}_{2}$ and aluminum oxide $\mathrm{Al}_{2} \mathrm{O}_{3}$ prevail in its composition constituting a share of $56 \%$ by weight, as well calcium oxide $\mathrm{CaO}$ and iron oxide $\mathrm{Fe}_{2} \mathrm{O}_{3}$ [3]. Similarly to basalt, the tested material shows quite a high crystallisation capacity, which supports the use of amphibolite dust for the manufacture of glass and ceramic products $[5,11]$.

\section{Mechanical toughness}

The results of preliminary amphibolite dust agglomeration tests, together with the mechanical toughness of obtained bodies, are presented in Table 5 .

On the basis of the presented results, unfavorable properties of starch-enhanced aggregates were found. Seasoning of body led to an increase in their Impact Strength Index, but the required values were not achieved. However, the results of the others research indicate the possibility of obtaining tough organic-binder aggregates in the compacting and briquetting processes $[1,7]$.

Satisfactory results of the drop tests were obtained for aggregates with cement as a binder. Finding the correct briquettes needs to be seasoned for a minimum of 48 hours. Increasing the binder's contribution raised the Impact 
Table 5. The results of gravitational dump test

\begin{tabular}{|c|c|c|c|c|}
\hline \multirow{2}{*}{ No. } & \multirow{2}{*}{1 Type of binder } & Binder share [\%] & \multicolumn{2}{|c|}{ Impact Strength Index [\%] } \\
\cline { 3 - 5 } & & & New-made sample & Seasoned sample at 48 $\mathrm{h}$ \\
\hline \multirow{3}{*}{1} & \multirow{3}{*}{2} & 10 & 57.0 & 65.2 \\
& \multirow{3}{*}{2} & 15 & 61.4 & 68.1 \\
& \multirow{3}{*}{ Ctarch } & 20 & 64.8 & 72.0 \\
& \multirow{3}{*}{ Cement } & 10 & 74.9 & 82.4 \\
& & 15 & 78.6 & 86.2 \\
& & 20 & 84.5 & 92.0 \\
\hline
\end{tabular}

Strength Index in the gravitational drop test. The best result on average of $92 \%$ was achieved for seasoned agglomerates with a $20 \%$ share of cement.

According to the literature, increasing in the proportion of binder with stone dust in the compound for agglomeration does not always produce positive results $[10,13]$. Acceptable bricks were obtained for the $15 \%$ addition of cement in a mixture of limestone and compressive strength was greater than $7 \mathrm{MPa}[6]$. In the case of the production of fine stone cobble cubes the cement content is from $15 \%$ to $30 \%$ [14]. It has been noted that attaining agglomerates depends on the molding process and on the range of pressure forces [7].

The authors have plans for further consolidation of stone dust with various types of cement along with the selection of its mass share. This will allow to obtain durable bricks that will be used in the construction industry.

\section{CONCLUSIONS}

On the basis of the results presented in the paper, it was stated that:

1. The amphibolite stone dust was defined as "hardly merged". The mechanical strength of new-made samples was insufficient, regardless of the type and proportion of the binder. No satisfactory results were obtained using a starch binder.

2. Seasoning for 48 hours increased the mechanical properties of agglomerates.

3. Agglomerates with acceptable toughness were found with the addition of cement in mass share $20 \%$, compressed in a hydraulic press at $50 \mathrm{MPa}$.

\section{REFERENCES}

1. Borowski G., Hycnar J.J., Józefiak T. 2016. Industrial briquetting trials for the waste management of bearing grinding. Annual Set The Environment Protection, Vol. 18, 205-217.

2. Cholerzyński A., Tomczak W., Świtalski J. 1999. Application of sulfur concretes for solidification of radioactive waste and construction of landfills (in Polish). Institute of Atomic Energy Annual Report, pp. 139-146.

3. Dobiszewska M. 2016. Use of basalt powder in a cementitious mortar and concrete as a substitute of sand. Construction and Architecture, 15(4), $75-85$.

4. Dobiszewska M., Franus W., Turbiak S. 2016. Analysis of the possibility of using powder basalt in cement mortar. Journal of Civil Engineering, Environment and Architecture, Vol. XXXIII, 63(1), 107-114.

5. Gacki F., Feliks J., Wyszomirski P., 2013. Research into the use of waste basalt dust (in Polish). Engineering and Chemical Engineering, 52(3), 174-175.

6. Galetakis M., Raka S. 2004. Utilization of limestone dust for artificial stone production: an experimental approach. Minerals Engineering, 17, 355-357.

7. Hycnar J.J., Borowski G., Józefiak T. 2014. Conditions for the preparation of stable ferrosilicon dust briquettes. Journal of the Polish Mineral Engineering Society, 33( 1), 155-162.

8. Kozioł W., Kawalec P. 2008. Alternative aggregates in construction (in Polish). Modern Engineering Construction, 7-8(18), 34-37.

9. Kozioł W., Uberman R. 1996. Możliwości i warunki zagospodarowania odpadów z górnictwa i energetycki w drogownictwie. zwłaszcza do budowy autostrad i dróg ekspresowych. Przegląd Geologiczny, 44(7), 701-709.

10. Lakhani R., Kumar R., Tomar P. 2014. Utilization of stone waste in the development of value added 
products: A state of the art review. Journal of Engineering Science and Technology Review, 7(3), 180-187.

11. Lubas M., Wyszomirski P. 2009. Unconventional application of Lower Silesian amphibolites. Ceramic Materials, 61(1), 31-34.

12. Mangena S.J., duCann V.M. 2007. Binderless briquetting of some selected South African prime coking, blend coking and weathered bituminous coals and the effect of coal properties on binderless briquetting. International Journal of Coal Geology, $71,303-312$.
13. Rajgor M., Pitroda J. 2013. Stone sludge: Economical solution for manufacturing of bricks. International Journal of Innovative Technology and Exploring Engineering, 2(5), 16-20.

14. Stankiewicz J. 2016. Directions of the management of small fraction arising in processing and extraction of mineral raw materials. Mining Science - Mineral Aggregates, 23(1), 155-166.

15. Wyszomirski P., Szydłak T. 2016. Fine grain fractions from basalts processing and their usefulness in ceramics. Mining Science-Mineral Aggregates, 23(1), 201-213. 